\title{
KONSTRIBUSI MASYARAKAT DALAM PARTISIPASI POLITIK SEBAGAI PENDUKUNG PEMBANGUNAN POLITIK DI INDONESIA
}

\author{
An Nisa ${ }^{1)}$,Agustinus Brahmantya Bima Saputra ${ }^{2)}$,Tirza Gracelia Putri ${ }^{3)}$,Anita Trisiana ${ }^{4)}$ \\ ${ }^{1,2,3)}$ Mahasiswa Akuntansi Universitas Slamet Riyadi Surakarta \\ ${ }^{4)}$ Dosen PPkN Universitas Slamet Riyadi Surakarta
}

\begin{abstract}
ABSTRAK
Pancasila merupakan Dasar Negara Indonesia dan sebagai pandangan hidup bangsa Indonesia. Sudah kita ketahui pancasila telah tercatat dalam UUD Negara Indonesia. Pancasila mempunyai fungsi sebagai Dasar Negara,ideologi Negara dan pandangan hidup bangsa Indonesia. Dalam sila pancasila telah tercantum salah satunya mengenai politik. Metode penelitian menggunakan deskriptif analitik yaitu suatu metode penelitian yang di lakukan dengan tujuan utama untuk membuat gambar atau deskripsi tentang suatu keadaan secara obyektif kemudian dianalisis untuk mencari hubungan antara dua variabel. Politik saat ini mempunyai peran penting bagi masyarakat,banyak masyarakat saat ini yang melalukan konstribusi guna ikut berpartisipasi politik terutama dalam mendukung pembangunan politik di Indonesia. Konstribusi sangat penting karena dengan adanya konstribusi dengan ikut serta masyarakat dalam partisipasi masyarakat bisa untuk memajukan dan mensukseskan pembangunan politik di Indonesia. Partisipasi masyarakat sangat diwajibkan karena merupakan bentuk kesadaran,tanggung jawab terhadap pentingnya suatu pembangunan politik. Pembangunan politik adalah satu bagian dari pembangunan nasional secara menyeluruh, dimana pembangunan itu bertujuan untuk memajukan demokrasi di Indonesia. Bentuk partisipasi masyarakat dalam mendukug pembangunan politik dengan cara keikutsertaan masyarakat dalam pembangunan politik guna mencapai kesejahteraan.
\end{abstract}

Kata kunci : Politik, Partisipasi, Pembangunan Politik.

\begin{abstract}
Pancasia is the basis of the state and as a view of the life of the Indonesia people. We already know that pancasia has been recorded in the Indonesian constitution. Pancasila has a funcition as the foundation of the state, the ideology of the state and the view of the Indonesia people. In the pancasila principle, one of them is about politics. Politics currently has an importa role for society, many people today are making contributions to participate in politics, especially in supporting political development in Indonesia. Constributions are very important because with the contributions of participating in the community participation can be able to advance and succeed in political development in Indonesia. Politic participation is very obligatory
\end{abstract}


because it is a from of awareness. Responsibility for the importance of political development is a part of overall national development. Where development aims to advance democrary in Indonesia. Forms of community participation in supporting political development by means of community participation in political development in order to achieve prosperity.

Keyword : politics,participation,political development

\section{PENDAHULUAN}

Politik yaitu, proses pembentukan dan pembagian keputusan dalam masyarakat untuk pengambilan keputusan dalam negara. Dalam politik salah satunya ada yang namanya pembangunan konstribusi masyarakat,partisipasi politik dan pembangunan politik.

Pembangunan politik adalah satu bagian dari pembangunan nasional secara menyeluruh, dimana pembangunan itu bertujuan untuk memajukan demokrasi di Indonesia,memajukan kehidupan sosial dan budaya yang tentram serta menggerakkan pertumbuhan ekonomi. Dalam pembangunan politik mencakup budaya politik,partai politik,stabilitas politik, demokrasi,dll. Dengan adanya pembangunan politik terciptalah konstribusi masyarakat dalam partisipasi politikdalam mendukung pembangunan politik . Di Indonesia saat ini banyak masyarakat berkonstribusi salah satunya dalam halpolitik.konstribusi tidak hanya dalam bentuk uang saja melainkan juga dalam bentuk pemikiran dan segala bentuk yang dapat mencapai tujuan yang telah di tentukan. Konstribusi politik dapat di lakukan dengan cara keikutsertaan dalam partai politik secara langsung maupun tidak langsung .
Partisipasi keikutsertaan masyarakat dengan mengidentifikasikan suatu masalah pemilihan dan pengambilan keputusan. Pertisipasi masyarakat merupakan hak dan kewajibanwarga Negara untuk memberikan konstribusinya. Sehingga memberikan kesempatan masyarakat untuk menyumbangkan kreatif dan inisiatis masyarakat. Bentuk partisipasi ini mengenai partisipasi politik. Partisipasi politik yaitu keikutsertaan warga Negara dari suatupembuatan keputusan sampai dengan pengambilan keputusan.

Partisipasi politik mengenai
pembangunan politik salah satunya. Masyarakat Indonesia berkonstribusi politik bukan dengan cara menggunakan uang,benda ataupun yang lainnya. Masyarakat Indonesia berkonstribusi dalam berpartisipasi politik sebagai pendukung pembangunan politik dengan caraikut serta dalam pemilihan umum,aktif dalam partai politik,berkampanye,adapun dalam bentuk konvensional dan non konvensional. Partisipasi politik merupakan kegiatan warga negara dalam mempengaruhi pengambilan keputusan pemerintah. Dalam pembangunan politik berhubungan dengan masalah pertisipasi dan keterlibatan rakyat dalam kegiatan politik (Trisiana, A: 2015). Dalam unsur adanya pelaksanaan hukum secara universal,semua orang harus taat pada hukum dan adanya kecakapan, dan prestasi serta bukan pertimbangan-pertimbangan 
status berdasarkan suatu sistem sosial yang tradisional. "menurut pye". Yang terpenting dari pembangunan politik adalah kedaulatan di tangan rakyat. Di Negara berkembang sering kali muncul kelabilan politik.

\section{METODE}

Dalam penelitian ini digunakan tipe deskriptif analitik. Metode penelitian menggunakan deskriptif analitik yaitu suatu metode penelitian yang di lakukan dengan tujuan utama untuk membuat gambar atau deskripsi tentang suatu keadaan secara obyektif kemudian dianalisis untuk mencari hubungan antara dua variabel. Metode ini digunakan untuk memecahkan atau menjawab permasalahan yang sedang di hadapi pada situasi sekarang(notoatmojo,2005)

Deskriptif analitik dapat di katakan suatu data ditampilkan agar infomasi yang di tampilkan dapat secara jelas di terima oleh orang lain .pemilihan dalam bentuk grafik atau table disesuaikan dengan data untuk tujuan yang akan di capai.

Dalam deskriptif analitik terdapat beberapa matrik yang digunakan untuk memberikan gambaran terhadap data yang kita punya. Sebelumnya deskriptif analitik di bagi menjadi empat jenis yaitu, deskriptif, prediktif, diagnostic, prektiptif. Metrikmatrik tersebut mempunyai peran dan interpretasi tersendiri. Deskriptif analitik hanya menggambarkan data yang ada dan tidak bertujuan untuk menarik kesimpulan pada suatu proposal.

\section{PEMBAHASAN}

\section{A. KONSTRIBUSI DAN PARTISIPASI}

\section{Pengertian konstribusi atau partisipasi}

Menurut Dany H, Yandianto
dalam kamus umum bahasa
Indonesia mengartikan konstribusi
sebagai bentuk iuran uang atau dana
pada suatu forum, perkumpulan dan
lain sebagainya. Dari pengertian di
atas konstribusi merupakan suatu bantuan berupa uang dalam mencapai tujuan yang diinginkan . Konstribusi tidak boleh hanya diartikan sebagai bantuan uang atau materi saja. Konstribusi dapat berupa ikut sertanya individu atau kelompok dalam suatu kegiatan. Salah satu dari bentuk konstribusi ialah konstribusi politik. Konstribusi politik merupakan keikutsertaan seseorang secara aktif dalam partai politik baik langsung maupun tidak langsung.

Begitu pula dengan partisipasi, Partisipasi merupakan keikutsertaan masyarakat dengan mengidentifikasikan suatu masalah, pemilihan dan pengambilan keputusan.

Dalam kegiatan politik setiap warga Negara ataupun masyrakat Indonesia berhak ikut dalam pembangunan politik. Juga memiliki hak untuk dapat mengikuti kegiatan politik. Masyarakat Indonesia juga dapat berpartisi pasi dalam pemerintahan mengambil kepitusan dengan cara memberikan kritik dan 
saran pada situs resmi lembaga Negara. Wujud lain dalam kegiatan aktif pembangunan politik adalah dengan mengikuti kampanmye sehat dan pemuli dengan menggukana asas LUBERJURDIL tanpa adanya pemaksaan.

Jenis-jenis partisipasi politik:

1. Partisipasi apatis adalah sikap masa bodoh, acuh tak acuh, tidak mau terlibat dan tertutup akan masalah atau proses politik yang ada dilingkungan sekitarnya atau negaranya. Contohnya seorang yang tidak mau ikut memberikan hak suaranya pada saat pemilu (golput).

2. Partisipasi spektor, adalah orang yang mengikuti pemulihan umum .

3. Partisipasi gladiator adalah seseorang yang ikut terlibat dalam politik yaitu memyampaikan informasi dengan tugas khusus mengadakan kontak tatap muka, aktivis partai.

4. Partisipasi pengkritik adalah orang yang berpartisipasi dalam bentuk tidak konvensional.

\section{PEMBANGUNAN POLITIK}

Pembangunan adalah perubahan yang mencakup system sosial, politik,ekonomi, infrastruktur,dsb Sedangkan politik adalah sebuah kegiatan di manakegiatan tersebut bertujuan untuk membuat keputusan Negara maupun daerah atau politik adalah sebuah kegiatan tentang pemerintahan. Jadi pembangunan politik bisa di artiakan sebuah langkah atupun cara di mana yang bertujuan untuk meningkatkan kualitas ataupun segalamacam politik.

Tujuan dari pembangunan politik yaitu:

1. Meningkat kualitas dalam pengambilan keputusan bagi para pejabat Negara

2. .mengurangi kegiatan $\mathrm{KKN}$ dalam pemerintahan

3. Meningkatkan kegiatan politik yang sehat

4. Meningkatkan kulaitas karakteristik bangsa dalam bidang politik

5. Meningkatkan kegiatan politik sehat yang mana kegiatan ini meliputi kegiatan- kegitan rapat yang berkualitas

Adapun juga mengenai tahap-tahap pembangunan politik yaitu:

1. Politik unifikasi primitive :dalam tahapan ini baru ada yang namanya tahap kelahiran/anak-anak. Yang belum fokus pada satu tujuan yakni kesejahteraan rakyat. Hal ini disebabkan karena mereka masih disibukan deengan aktualisasi diri dan bagimana menciptakan persatuan nasional.

2. Politik industrialisasi: dalam tahap ini terdapat suatu kelas baru yang memegang kekuasaan untuk membangun ekonomi suatu Negara. Dalam membangun ekonominya Negara tersebut memiliki acuan pada negara- negara yang sudah maju sehingga mereka menganut sistem demokrasi barat, pemerintahan 
komunis atau fasis yang menjadi cermin suatu bangsa memasuki tahap industrialisasi.

3. Politik kesejahteraan nasional : dengan timbulnya sebuah usaha antara rakyat dengan pemerintah dengan bentuk dan wujud yang sempurna, dengan bentuk dan wujud yang semakin sempurna. Pemerintahberkewajiban

menetapkan undang-undang kesejahteraan warga.

4. Politik berkelimpahan: tahap ini dimulai suatu revolusi industri baru merupakan sebuah revolusi otomatis. Pemerintah memiliki fungsi memberikan dasar bagi pengaturan dan pengoorganisasian yang baru dalam menciptakan damainya masyarakat.

\section{Aspek-aspek PembangunanPolitik}

1. Pembangunan politik sebagai persyaratan politik untuk pembangunan ekonomi: untuk yang terutama pemerintah di pusatkan pada suatu masalah mengenai pembangunan ekonomi dengan perlunya merubah suatu ekonomi yang statis men. Oleh sebab itu wajarlah kalau jadi ekonomi yang berjalan dengan sendirinya. Pembangunan politik di pandang sebagai keadaan masyarakat politik yang dapat meluncurkan pertumbuhan ekonomi.

2. Pembangunan politik sebagai modernisasi politik: Dalam suatu kehidupan yang ideal dari masyarakat sangat perpegang pada pandangan bahwa suatu pembangunan politik sama dengan modernisasi politik.

3. Pembangunan politik sebagai usaha untuk mewujudkan Negara kebangsaan

4. Pembangunan politik sebagai pembangunan administrasi danhukum: jika kita bagi pembinaan bangsa kedalam pembinaan lembaga-lembaga dan pembinaan kewarganegaraan timbulah dua pengertian pembangunan politik yang sering kita jumpai.

5. Pembangunan politik sebagai mobilisasi massa,partisipsi rakyat dan kekuasaan : kesadaran bahwa system politik dapat memenuhi ukuran prestasi dan manfaat bagi masyarakat bahwa kita pada pandangan mengenai pembangunan politik sebagai kadar kesanggupan suatu sistem.

6. Pembangunan politik slah satunya sebagai pembunaan suatu demokrasi.

7. Pembangunan politik sebagai stabilitas dan suatu perubahan secara tertib

\section{Hakikat Pembangunan Politik Di Indonesia}

pembangunan politik bangsa Indonesia mempunyai tantangan yang rill ketika 
di bentuknya Negara Republik Indonesia. Degan ini mulai pembaharuan politik Indonesia mengharapkan akan terwujudnya tata kehidupan politik yang siap membawa cita-cita bangsa Indonesia yaitu masyarakat yang adil dan makmur. Dengan ini nilai-nilai pancasila di dalam kehidupan dapat tercapai. Disamping itu kita dapat memanfaatkan pemikiran tentang pembangunan politik yang berkembang di dunia adar tida bertentangan dengan nilai-nilai ideologi Pancasila.

\section{Pembangunan Politik Di Indonesia Mendukung Nilai Tertentu}

Dari kondisi keterbelakangan sebagai akibat eksploitasi sistem politik kolonial,kita ingin menuju kearah tercapainya masyarakt yang adil,makmur,dan sejahtera yang merupakan hasil dari kehidupan bersama di dalam suatu system politik yang merdeka. Di tinjau dari segi proses dan dengan memperhatikan unsur-unsurnya yang relevan, maka pembangunan politik itu dapat di lihat sebagai himpunan perubahan-perubahan politik baik struktur maupun kultural, yang dapat diidentifikasikan secara historis dan yang bersangkutan dengan usaha pengalaman nilai-nilai yang dijadikan pandangan hidup dari suatu bangsa serta demi terciptanya tujuan nasional yang dicita-citakan oleh bangsa itu. Batas pengertian tentang pembangunan politik tersebut walaupun sangat sederhaana ungkapannya,namun dapat di jadikan landasan berpijak di tengah-tengah masalah pembangunan yang kenyataanya sangat rumit saat ini.

\section{Ciri Pokok Pembangunan Politik}

Yang pertama, bersangkutan dengan usaha untuk merealisasikan semangat atau sikap yang pada waktu sekarang ini sangat besar pengaruhnya di kalangan bangsabangsa di dunia yaitu, semangat atau sikap yang mendambakan kesamaan. Dibidang politik, hal ini akan menyangkut partisipsi massa dan keikutsertaan rakyat dalam kegiatan politik.

Yang kedua, bersangkutan dengan kapabilitas suatu sistem politik. Sistem politik yang sudah berkembang dipandang mampu untuk melakukan tugas yang jauh lebih banyak, dan lrbih berat dibandingkan sistem politik yang belum berkembang.

Yang ketiga. Menyangkut gejala yang paling banyak dibicarakan dalam pembahasan tentang pembangunan politik. Secara lebih konkret, maka proses pembangunan politik itu bisa dilihat semakin berfungsinya golongan-golongan palitik sebagai lembaga-lembaga infrastruktur ,semakin meningkatnya partisipasi politik, dan profesi semalin lama semakin bertambahnya pula jumlahnya.

Munculnya gejala-gejala tersebut dalam kenyataannya tidak dipisahkan dari perkembangan sejumlah bedar segi kehidupan di bidang sosial dan ekonomi yang bisa di pandang sebagai persyaratan bagi dimungkinkannya proses pembangunan politik, seperti tingkat pendapatan perkapita, presentase dari rakyat yang sudah melek huruf, tingkat perkembangan dibidang komunikasi dan trasportasi dan jalan kereta 
api yang ada beserta angka pertumbuhannya,jumlah pembaca surat kabar ,jumlah radio/televise yang dimiliki atau sebagainya. Proses pembangunan politik tidak akan dapat tingkat perkembangan yang cukup berarti tidak di dukung oleh hasil-hasip pembangunan sosial-ekonomi

\section{B. PARTISIPASI \\ DALAM POLITIK}

\section{MASYARAKAT PEMBANGUNAN}

Dari konstribusi masyarakat dalam partisipasi politik merupakan keikutsertaan masyarakat dalam partai politik dengan mencapai tujuan yang telah di tentukan. Cara masyarakat melakukan partisipasi politik salah satunya dengan cara pembangunan politik yaitu dengan aktif dalam partai

Dari penjelasan di atas dapat di simpulkan bahwa konstribusi politik merupakan cara keikutsertaan masyarakat dalam politik bukan hanya dalam bentuk uang atau benda tetapi dalam bentuk pemikiran,dengan menyumbangkan kreatif dan inovatif. Begitu juga dengan partisipasi politik,masyarakat juga ikut serta aktif dalam partai politik salah satunya dengan mendukung mengenai pembangunan politik yang ada di Indonesia. Dalam pembangunan politik masalah yang di hadapi, seperti tingkat pendapatan perkapita, presentase dari rakyat yang sudah melek huruf, tingkat perkembangan dibidang komunikasi dan trasportasi dan jalan kereta api yang ada beserta angka pertumbuhannya. Begitu juga politik secara langsung atau tidak langsung, dan juga secara konvensional dan nonkonvensional. Secara konvensional meliputi : pemberian suara, pengajuan revisi dan berkampanye. Sedangkan secara non konmvensional meliputi : berdemostrasi, konfrontasi, mogok, tindakan kekerasan politik, tindakan kekerasan terhadap manusia, penculukan, pembunuhan, dll. Namun banyak masyarakat juga enggan ikut dalam berpartisipasi karena kurangnya informasi mengenai politik. Dan adapun masalah mengenai pembangunan politik yaitu salah satunya pendapatan per kapita.

\section{PENUTUP}

\section{Kesimpulan}

dengan pertisipasi politik dengan cara ikutserta aktif dalam partai politik dan pemilihan umum

\section{Saran}

Bagi mahasiswa

Bagi mahasiswa bisa lebih mendukung adanya pembangunan pilitik di Indonesia dan ikut berpartisipasi dalam politik dengan adil demi terciptanya tujuan yang di inginkan

Bagi masyarakat

Lebih bisa berkonstribusi dalam hal partisipasi politik dengan jujur dan mendukung adanya pembangunan politik di Indonesia saat ini. 


\section{DAFTAR PUSTAKA}

Amirmachmud H.1987. Pembangunan Politik Dalam Negeri Indonesia.Jakarta:PT Gramedia.

Haryono.(2008).Birokrasi dan pembangunan politik,26.73-86.

Kanalan, E.(2011). A glance to education in the middle east under the shadow of politic and ethnic conflicts in the region.15.2864-2868.

Munandar,H.1994.Pembangunan Politik Situasi Global Dan Hak Asasi Di Indonesia.Jakarta: PT Gramedia Pustaka Utama.

Sajnani, N. (2013). The body politic: the relevance of an intersectional framework fortherapeutic performance research in drama therapy. the art in psychotherapy.40.382-385.

Simamora,S.1985, Pembagunan Politik Dalam Prespektif, Jakarta:PT bina Aksara.

Sudarsono,J.1976,.Pembangunana Politik Dan Perubahan Politik.Jakarta:PT Gramedia.

Ridha M. (2016). Ekonomi Politik Pembangunan Infrastruktur Dan Kepentingan Kapitaljurnal politik profetik,04.

Rosana,E.(2012). Partai Politik dan Pembangunan Politik,08.
Terchilia,S. (2014).The activity offmass media companies in europe. The impact generated in the economic,social, and politic systems.scienceDirect,16.182189.

Trisiana, A. (2015). The Development Strategy of Citizenship Education In Civic Education Using Project Citizen Model In Indonesia. Jurnal Of Psychological And Educational Research (JPER),23 (2),51. 